\title{
Traumatic life history and co-existing psychiatric disorders in adolescents with a diagnosis of conversion disorder
}

\section{Konversiyon bozukluğu olan ergenlerde travmatik yaşam öyküsü ve komorbid psikiyatrik hastalıklar}

Seda Aybüike Sarı ${ }^{1}$, Emine Çığıl Fettahoğlu ${ }^{2}$, Esin Özatalay ${ }^{3}$, Ayla Uzun ${ }^{4}$

${ }^{1}$ Child and Adolescent Mental Health and Diseases Clinic (S.A Sar1, MD), Bitlis State Hospital, Bitlis, Turkey
${ }^{2}$ Psychiatrist (E.C. Fettahoğlu, MD), Antalya, Turkey
${ }^{3}$ Department of Child and Adolescent Mental Health and Diseases, (Assist. Prof. E. Özatalay), Akdeniz University Medicine
of School, Antalya, Turkey
${ }^{4}$ Department of Child and Adolescent Mental Health and Diseases (Assist. Prof. A. Uzun), Cumhuriyet University Medicine
of School, Sivas, Turkey
Corresponding author: Ayla Uzun MD, Department of Child and Adolescent Mental Health and Diseases, Cumhuriyet
University Medicine of School, Sivas/ Turkey
E-mail: dr.f.ayla @ hotmail.com
Received/Accepted: December 29, 2015 / August 10, 2016
Conflict of interest: There is not a conflict of interest.

\section{SUMMARY}

Objective: The aim of this study was to determine the relation between the perception of self and other important individuals', the ways of this perception and the self-esteem, comorbid psychopathologies and the traumatic experiences in adolescents took the diagnosis of Conversion Disorder (CD).

Method: A total of 20 adolescent girls aged 12-18 took the diagnosis of CD and have still being followed were included in the study as experimental group and 20 healthy girl adolescents paired with the experimental group in the terms of age, gender, educational status. Both of groups were evaluated with Schedule for Affective Disorders and Schizophrenia for School-Age ChildrenPresent and Lifetime Version, Rosenberg Self- Esteem Scale.

Results: Adolescents with CD have more psychopathology levels, lower self-esteem. Traumatic experiences, including sexual abuse in particular have been identified in patients more commonly than the controls.

Discussion: $C D$ is usually accompanied with mood disorders. These are followed by anxiety disorders, dissociative disorders and personality disorders respectively. In a study, patients who experienced pseudoseizures have been reported to have borderline personality disorders by $\% 55$, histrionic personality disorder by $\% 16$ and, antisocial personality disorder by $\% 11$.

Keywords: Adolescent, conversion disorder, traumatic experiences, psychopathology and selfesteem.

ÖZET

Amaç: Bu araştırmada Konversiyon Bozukluğu (KB) tanısı almış ergenlerin benlik saygıları, KB'ye eşlik eden psikopatolojiler, yaşadıkları travmatik deneyimler arasındaki ilişkilerin araştırılması amaçlanmıştır.

Yöntem: Araştırmaya Konversiyon Bozukluğu tanısı almış ve izlemde olan 12-18 yaş aralığında 20 kız ergen ile yaş, cinsiyet, eğitim durumu açısından hasta grubu ile eşleştirilmiş 20 sağlıklı kız ergen alınmıştır. Hasta ve kontrol gruplarına Rosenberg Benlik Saygısı Ölçeği, Okul Çağı Çocukları için Duygulanım Bozuklukları ve Şizofreni Görüşme Çizelgesi-Şimdi ve Yaşam Boyu Versiyonu uygulanmiştır. 
Bulgular: KB tanısı alan ergenlerin kontrol grubuna göre benlik saygılarının daha kötü olduğu ve başka ruhsal bozuklukların sık olarak eşlik ettiği görülmüştür. KB'li ergenlerde başta cinsel istismar olmak üzere travmatik yaşantı daha sık tanımlanmıştır. Tartışma KB'ye en sık duygudurum bozuklukları eşlik eder. Bunu sırasıyla anksiyete bozuklukları, dissosiyatif bozukluklar vekişilik bozuklukları izler. Yapılan bir çalışmada psödonöbet geçiren hastalarda borderline kişilik bozukluğu $\% 55$, histrionik kişilik bozukluğu \%16 antisosyal kişilik bozukluğu \%11 oranında bildirilmiştir.

Sonuç: KB'ye eşlik eden sorunların erken tanınması, sağaltımda göz önünde bulundurulması ve işlenmesi erişkin yaşta gelişebilecek kimlik patolojilerin ve eşlik eden diğer psikopatolojilerin önlenmesi açısından oldukça önemlidir.

Anahtar sözcükler: Ergen, konversiyon bozukluğu, travmatik yaşantılar, psikopatoloji ve benlik saygis1.

\section{INTRODUCTION}

Conversion disorder (CD) is a psychiatric disorder that effects sensory or voluntary motor skills, reminiscent of neurological or another general medical condition with one or more co-existing symptoms ${ }^{1}$. While CD is a rare condition in Western countries, it is still a common disorder in Eastern countries. In our country, its prevalence is reported as \%2-3 in child and adolescent psychiatry clinics ${ }^{2}$. Even though CD is almost equally seen in both genders before puberty, it is much more common in females after puberty and there are 2-10 female patients per 1 male patient. Also, it is more common in individuals who live in the countryside and with low educational and socioeconomic levels ${ }^{1,3,4}$.

CD might mimic most of known medical diseases due to similarities of sensory, voluntary motor and neurovegetative symptoms. This situation extends the time period until diagnosis and treatment; thus causing additional psychiatric pathologies. It is known that mostly mood disorders coexist with $\mathrm{CD}$, followed by anxiety disorders, disassociative disorders, personality disorders and somatoform disorder ${ }^{5}$. Also there are many studies that report sexual abuse and traumatic life histories in early childhood are associated with conversion symptoms ${ }^{6,7}$.

In this study, we aimed to analyze the correlation among self-esteem levels, coexisting psychopathologies and traumatic life experiences in 12-18 years old adolescents who were diagnosed as $\mathrm{CD}$ in a 6 months period, compared to control group.

\section{MATERIAL AND METHOD}

This study included 20 female adolescents who were between the ages of $12-18$ and diagnosed with CD. Akdeniz University Medicine of School, child and adolescent psychiatry clinics in last 6 months. Exclusion criteria included impaired mental development and disorders that may affect reality testing such as mania or psychotic disorder. Control group included 20 voluntary adolescents who were matched to patient group in age, gender and education level and didn't have a story of child and adolescent psychiatry clinic visit, impaired mental development and any current psychiatric disorder that might affect reality testing (such as psychosis and mania). This study is approved by Akdeniz University Ethics Committee on Experimentation on Human Beings in line with Helsinki Declaration. Written consent of parents and consent of adolescents were retained before the study.

\section{Data Collection Tools}

Sociodemographic Data Questionnaire: The questionnaire formed by the researcher includes demographic characteristics of adolescents such as age, gender, education level, academic success, income level, psychiatric and medical disease story of their family and residence. This questionnaire also included data about previous traumatic experiences, familial or environmental stressors, reason of medical consultation, duration and frequency of complaints, type of signs and other coexisting somatic symptoms. 
Rosenberg Self-esteem Scale (RSES): This scale was created by Rosenberg ${ }^{8}$ to evaluate self-esteem. This scale is used to analyze positive and negative aspects of self-esteem and Turkish validity and reliability study was reported by Çuhadaroğlu9. This scale consists of 63 multiple-choice questions in 12 subcategories.

Kiddie Schedule for Affective Disorders and Schizophrenia for School Aged Children- Present and Lifetime Version (K-SADS-PL): K-SADS-PL is a semiconstructed diagnosis interview in order to identify previous and current psychopathologies in children and adolescents according to DSM III and DSM IV diagnosis criteria ${ }^{10}$. Validity and reliability in Turkish cohort was reported by Gökler et al. ${ }^{11}$. It includes diagnosis of major depression, dysthymia, mania, hypomania, cyclothymia, bipolar disorder, schizoaffective disorders, schizophrenia, schizophreniform disorder, brief reactive psychosis, panic disorder, agoraphobia, separation anxiety disorder, avoidant personality disorder, simple phobia, social phobia, severe anxiety/ generalized anxiety disorder, obsessive compulsive disorder (OCD), attention deficit-hyperactivity disorder, conduct disorder, oppositional defiant disorder, enuresis, encopresis, anorexia nervosa, bulimia, transient tic disorder, Tourette disorder, chronic motor or vocal tic disorder, alcohol and substance addiction and post-traumatic stress disorder. K-SADS-PL is applied by interviewing with parents and child and evaluated by data from all sources in the end. If there is any discordance between collected data, clinician uses his/her own judgement. K-SADS-PL evaluates previous and current symptoms as "absent", "subthreshold" and "present" and do not inform about the severity of symptoms.

\section{RESULTS}

There were no statistical differences between control group and $\mathrm{CD}$ group in terms of age and education level, academic success, location of residence, family structure, family income, ages of parents, education levels of parents and occupations of parents ( $p>0,05$; Table 1$)$. None of the patients with $\mathrm{CD}$ diagnosis arrived to our clinic directly. Table 2 shows demographic data of CD patient group. A great majority (\%70, n: 14$)$ of these adolescents were referred from emergency department, while rest $(\% 30$, n: 6) was evaluated by child and adolescent psychiatry outpatient clinic after consultation requests of pediatric and cardiology clinics mainly. Main complaint to these departments were faint (n: 16, \%80), followed by paresthesia-contraction (n: 5, \%25) and weakness (n: 4, \%20).

More than half of patients (\%55) define four or more conversion episodes in a month. Although these complaints were frequent in majority of cases, mean time to arrive at child and adolescent psychiatry clinic was $6.8 \pm 6.2$ months. Most common conversion type was mix type with 55\% ratio (n: 11 ) and pseudoseizure was the second most common type (35\%, n: 7). Only $10 \%$ of patients (n: 2) described sensory type. La belle indifference was observed in few cases (20\%). In addition to conversion symptoms, somatic complaints were reported in $80 \% 80$ of patients and headache was the most common somatic complaint. One third of patients with CD had a parental psychiatric disorder diagnosis history. Two third of the patients mentioned presence of both familial and environmental stressors. Patients defined familial stressors as marital conflict, argument, sibling conflict, harsh punishments of parents, high academic expectations; while environmental stressors were defined as low levels of academic achievements, peer-conflicts, exclusion, and low socioeconomic level. 
Table 1. Sociodemographic Parameters

\begin{tabular}{|c|c|c|}
\hline & Patient $(n=20)$ & Control $(n=20)$ \\
\hline Age (year) & $15.3 \pm 1.4$ & $15,5 \pm 1,2$ \\
\hline Educational status (year) & $9 \pm 1.5$ & $9.4 \pm 1.3$ \\
\hline $\begin{array}{l}\text { Place of residence } \\
\text { Province } \\
\text { County }\end{array}$ & $\begin{array}{c}13(\% 65) \\
7(\% 35)\end{array}$ & $\begin{array}{c}16(\% 80) \\
4(\% 20)\end{array}$ \\
\hline $\begin{array}{l}\text { Academic achivement } \\
\text { Well } \\
\text { Medium } \\
\text { Bad }\end{array}$ & $\begin{array}{l}3(\% 15) \\
15(\% 75) \\
2(\% 10)\end{array}$ & $\begin{array}{l}4(\% 20) \\
12(\% 60) \\
4(\% 20)\end{array}$ \\
\hline $\begin{array}{l}\text { Age (year) } \\
\text { Educational status (year) }\end{array}$ & $\begin{array}{c}41.1 \pm 7.3 \\
7.3 \pm 3.8\end{array}$ & $\begin{array}{c}39.4 \pm 4.6 \\
9 \pm 3.8\end{array}$ \\
\hline $\begin{array}{l}\text { Mother's Job } \\
\text { Not working } \\
\text { Working }\end{array}$ & $\begin{array}{l}11(\% 55) \\
9(\% 45)\end{array}$ & $\begin{array}{l}11(\% 55) \\
9(\% 45)\end{array}$ \\
\hline $\begin{array}{l}\text { Age (year) } \\
\text { Educational status (year) }\end{array}$ & $\begin{array}{c}46.2 \pm 6.8 \\
8.8 \pm 3.6\end{array}$ & $\begin{array}{c}44.9 \pm 3.9 \\
9.9 \pm 3.8\end{array}$ \\
\hline $\begin{array}{l}\text { Father's job } \\
\qquad \begin{array}{l}\text { Not working } \\
\text { Craftsmen } \\
\text { Employee } \\
\text { Officer }\end{array}\end{array}$ & $\begin{array}{c}1(\% 5) \\
4(\% 20) \\
10(\% 50) \\
5(\% 25)\end{array}$ & $\begin{array}{l}1(\% 5) \\
7(\% 35) \\
7(\% 35) \\
5(\% 25)\end{array}$ \\
\hline $\begin{array}{l}\text { Family structure } \\
\qquad \begin{array}{l}\text { Nuclear Family } \\
\text { Extended Family } \\
\text { Divorced }\end{array} \\
\end{array}$ & $\begin{array}{l}19(\% 95) \\
1(\% 5)\end{array}$ & $\begin{array}{l}15(\% 75) \\
2(\% 10) \\
3(\% 15)\end{array}$ \\
\hline $\begin{array}{l}\text { Income Level } \\
\qquad \begin{array}{l}\text { Well } \\
\text { Medium } \\
\text { Bad }\end{array}\end{array}$ & $\begin{array}{c}5(\% 25) \\
11(\% 55) \\
4(\% 20)\end{array}$ & $\begin{array}{c}6(\% 30) \\
10(\% 50) \\
4(\% 20)\end{array}$ \\
\hline
\end{tabular}


Table 2. Demographic data of conversion disorder group

\begin{tabular}{|c|c|}
\hline Patient Group & n $(\%)$ \\
\hline $\begin{array}{l}\text { Aplication place } \\
\qquad \begin{array}{l}\text { Emergency service } \\
\text { Outpatient clinic of pediatrics }\end{array}\end{array}$ & $\begin{array}{c}14(70 \%) \\
6(\% 30) \\
\end{array}$ \\
\hline $\begin{array}{ll}\text { symptom } & \\
& \text { Fainting } \\
\text { Numbness-contraction } \\
\text { Weakness } \\
\text { Frequency of symptoms * } \\
\\
& 1 \\
& 2 \\
& 3 \\
& 4+ \\
\end{array}$ & $\begin{array}{c}16(\% 80) \\
5(\% 25) \\
4(\% 20) \\
4(20) \\
2(10) \\
3(15) \\
11(55) \\
\end{array}$ \\
\hline Mean time to arrive at child and adolescent pscyhiatry $*$ & $6.8 \pm 6.2$ \\
\hline $\begin{array}{l}\text { Stress factors } \\
\qquad \begin{array}{l}\text { family } \\
\text { Environmental } \\
\text { Both of } \\
\end{array} \\
\end{array}$ & $\begin{array}{c}2(10) \\
3(15) \\
15(75)\end{array}$ \\
\hline $\begin{array}{l}\text { Symptom type } \\
\text { Sensory } \\
\text { Pseudoseizures } \\
\text { Mix type } \\
\end{array}$ & $\begin{array}{l}2(10) \\
7(35) \\
11(55)\end{array}$ \\
\hline $\begin{array}{l}\text { Traumatic experiences } \\
\qquad \begin{array}{l}\text { Sexual } \\
\text { Sexual+ physical } \\
\text { Physical } \\
\text { physical + emotional }\end{array}\end{array}$ & $\begin{array}{l}4(20) \\
1(5) \\
1(5) \\
1(5)\end{array}$ \\
\hline La bela indiferance & $4(\% 20)$ \\
\hline Comorbid somatic symptoms & $16(80)$ \\
\hline Suicidal attempt & $11(55)$ \\
\hline Substance abuse & $7(35)$ \\
\hline Comorbid physical illness & $1(5)$ \\
\hline Family history of pscyhiatric disorders & $7(35)$ \\
\hline Conversion disorder in family & $3(15)$ \\
\hline
\end{tabular}

*The frequency of conversion attacks occuring in a month

All patients included in the study were questioned about their past-traumatic experiences. While there were no traumatic experiences in control group, more than one third of adolescents with $\mathrm{CD}(\% 35)$ reported at least one traumatic incident in past. Most common reported traumatic experience was sexual abuse (n: 4, \%20). We observed pseudo-seizure or mix-type $\mathrm{CD}$ in all patients who reported sexual abuse in the past. More than half of adolescents with CD (\%55) reported at least one suicidal attempt, more than one third of patients (\%35) reported use of substance at least once. We didn't find any suicidal attempt or substance use in control group.

When we examined the scores of Rosenberg Self-esteem Scale (RSES), mean score of adolescents with CD diagnosis $\quad(12,70 \pm 5,59) \quad$ were significantly lower than control group $(20,70 \pm 4,87)(\mathrm{t}=4,83, \mathrm{df}=38 \mathrm{p}<0,001)$.

All adolescents in this study were evaluated with semi-structured interview (KSADS-PL) for psychopathology. Accordingly, \%85 of adolescents with $\mathrm{CD}$ (n: 17) had at least one additional mental disorder. One third of adolescents in control group (\%35) had at least one mental disorder. Thus, adolescents with CD had significantly more psychopathology comparing to their nonCD peers ( $p<0,01, x 2: 10.41)$. Also eight of adolescents with CD (\%80) had more than one coexisting psychopathology. None of the adolescents in control group had multiple psychopathology. Most common coexisting disorders in adolescents with $\mathrm{CD}$ were mood 
disorders (\%75), oppositional defiant disorder (ODD) (\%20), post-traumatic stress disorder (PTSD) (\%15) and social phobia (\%10). Mental disorders identified in control group differ greatly. Distribution of psychiatric disorders in adolescents is shown in Table 3.

Table 3. Distribution of psychiatric disorders in adolescents

\begin{tabular}{|l|c|c|}
\hline & Patient $\mathbf{n}(\boldsymbol{\%})$ & control $\mathbf{n}(\%)$ \\
\hline Diagnosed $^{*}$ & $17(85)$ & $7(35)$ \\
\hline Mood disorder & $15(75)$ & $2(10)$ \\
\hline Anxiety disorders & $1(5)$ & 0 \\
\hline Social phobia & $2(10)$ & $2(10)$ \\
\hline ADHD & $1(5)$ & $1(5)$ \\
\hline ODD & $4(20)$ & $1(5)$ \\
\hline PTSD & $3(15)$ & 0 \\
\hline
\end{tabular}

*number of adolescent diagnosed at least one psychiatric disorder with K-SADS

\section{DISCUSSION}

First important finding of this study is that coexisting mental disorders are very common in adolescents with CD. Even almost half of cases (40\%) had more than one coexisting psychopathology. Major depression, ODD, and PTSD were among the most common psychopathologies. This finding is in accordance with literature. It is a known fact that additional mental disorders, especially mood disorders, often accompany to $\mathrm{CD}$ in both adult and childadolescent psychiatry studies ${ }^{6,12-14}$. Secondly, self-esteem levels of these adolescents were lower than their peers. Self-esteem level of an individual is reported to have an effect on resistance against psychological and physiological disorders and skills on communication ${ }^{15}$. There is not enough data about selfesteem levels of adolescents with CD in literature. Sexual or physical abuse and family problems are often reported in the studies of $\mathrm{CD}$. It can be seen that psychological factors such as siblingconflict, problems in school, concerns about academic success, high expectations of family, fears of death and physical disorders, separation concerns or communication problems might have a role in $\mathrm{CD}$. Conflicts or communication difficulties are known to exist in families of children with $\mathrm{CD}^{16,17}$. Inferiority of self-esteem might be caused by unresolved stressor factors, misunderstanding of adolescent by people or even his/her family, thought of primary gain or acting, social exclusion and loneliness and lower resistance against these stressors comparing to peers.

All adolescents in our study were questioned about past traumatic experiences. Adolescents with $\mathrm{CD}$ reported frequent traumatic experiences and most common experience was sexual abuse. All adolescents suffer sexual abuse showed pseudo-seizure or mix type seizure. While childhood trauma story was researched in $C D$ as much as other disorders, Subtype of CD accompanied with pseudo-seizure was the most frequently reported in patients with sexual or physical trauma experiences $^{18,19}$. Even though rate of this experiences vary between $25 \%$ and $70 \%$, importance of these traumas are accepted in almost all studies ${ }^{13,18,20,21}$. Our study showed similar results. If there are pseudo-seizure or mix type CD symptoms in adolescents, especially who admitted to the emergency service, traumatic experiences such as sexual abuse must be questioned.

Another striking aspect of this study is that none of the adolescents arrived to our clinic directly. Also, it tooks approximately 6 months for these 
patients to visit child and adolescent psychiatry clinic. This period is extended due to differentiation of organic etiologies in other clinics. Even some patients were diagnosed as epilepsy and followed with anti-epileptic treatment, then referred to us after continuation of seizures. This period might extend to years. Extension of this period might cause identity formation of the patient and addition of other mental disorders; thus causing lower response to treatment and unfavorable prognosis. Also, untreated $\mathrm{CD}$ is suggested as the cause of somatization, anxiety disorder or personality disorder in adult life $\mathrm{f}^{19,22,23}$.

Considering our finding that adolescents with $\mathrm{CD}$ arrive to other pediatric departments, clinicians in other departments must be informed about this disorder.

\section{REFERENCES}

1. Ford CV, Folks DG. Conversion disorders: an overview. Psychosomatics 1985; 26: 371-83.

2. Kerimoğlu E. Yalın A. Obsessivecompulsive disorder and hysteria (conversion reaction) in children. Journal of Ankara Medical School 1992; 14: 11-8.

3. Guze SB, Woodruff RA, Clayton PJ. Sex, age and the diagnosis of hysteria. Am J Psychiatry 1972; 129: 121-4.

4. Çelikel F, Saatçioğlu Ö. Konversiyon bozukluğunda aleksitiminin depresyon ve anksiyeteye etkisi. Klinik Psikiyatri 2002; 5: 229-34.

5. Doğan O. Konversiyon bozukluğu. Köroğlu E, Güleç C. Psikiyatri Temel Kitabı. Bask1, Ankara HYB Basın Yayım 2007; 377-85.

6. Rechlin T, Loew TH, Joraschky P. Pseudoseizure 'Status'. J Psychosom Res 1997; 42: 495-8.

7. Kaygisız A, Alkın T. Konversiyon bozukluğunda 1 . ve 2 . eksen ruhsal bozukluk eştanıları. Türk Psikiyatri Dergisi 1999; 10: 33-9.

8. Şar V, Akyüz G, Kundakçı T. Chilhood trauma, dissociation and psychiatric comorbidity in patients
When we evaluated adolescents in our study, we observed that CD patients had more traumatic life experiences, especially sexual abuse, comparing to control group. Also, it is found that CD effects self-esteem negatively. Also in our study, $85 \%$ of adolescents with CD showed at least one coexisting psychiatric disorder. Depressive disorder, ODD, PTSD were the most frequent diagnosis. For this reason, coexisting psychopathologies in CD must be evaluated and previous traumatic experiences must be questioned.

Early differential diagnosis of $\mathrm{CD}$ with organic pathologies and treatment can only be achieved with a multidisciplinary approach of all pediatric departments.

with conversion disorder. Am J Psychiatry 2004; 161: 2271-6. J.

9. Rosenberg M. Society and the adolescent self-image. New Jersey: Princeton University Pres 1965.

10. Çuhadaroğlu F. Adölesanlarda benlik saygisi. Hacettepe Üniversitesi Tip Fak Psikiyatri AD Yayımlanmamış Uzmanlık Tezi, Ankara 1986.

11. Kaufman Birmaher B, Brent D. Schedule for affective disorders and schizophrenia for school-age children-present and lifetime version (K-SADS-PL): initial reliability and validity data. J Am Acad Child Adolesc Psychiatry 1997; 36: 980-8.

12. Gökler B, Ünal F, Pehlivantürk B. Okul çağı çocukları için duygulanım bozuklukları ve şizofreni görüşme çizelgesi-şimdi ve yaşam boyu şekliTürkçe uyarlamasının geçerlik güvenirliği. Çocuk ve Gençlik Ruh Sağl1 ğ1 Dergisi 2004; 11: 109-16.

13. Özen Ş, Özbulut Ö, Altındağ A. Acil serviste konversiyon bozukluğu tanis1 konan hastaların sosyodemografik özellikleri, stres faktörleri, I. ve II. eksen eştanılar. Türkiye'de Psikiyatri 2: 87-96.

14. Bowman ES, Markand NO. Psychodynamics and Psychiatric 
Diagnoses of 33 Pseudoseizures Subjects. Am J Psychiatry 1996; 153: 57-63.

15. Kerimoğlu E. Çocukluk çağı nevrotik bozuklukları. Ankara Kent Matbaası 1996; 390-93.

16. Pehlivantürk B, Unal F. Conversion disorders in children and adolescents; clinical features and comorbiditywith depressive and anxiety disorders Turk J Pediatr 2002; 42: 132-7.

17. Grattan Smith P, Fairley M, Procopis P. Clinical features of converison disorder. Arch Dis Child 1988; 63: 408-14.

18. Pehlivantürk B. Somatoform Bozukluklar. Çocuk ve ergen psikiyatrisi Temel Kitab1, 1. Bask1 Ankara HYB Basım Yayın Matbaas1 2008; 423-37.

19. Griffth JL, Polles A, Griffith ME. Pseudoseizures, families and unspeakable dilemmas. Psychosomatics 1998; 39: 14453.

20. Nemzer ED. Psychosomatic ilness in children and adolescents. Pyschiatric disorders in children and adolescents, BD Garfinkel, GA Carlson, EB Weller (eds.) Saunders Company. Philadelphia 1990; 135-46.

21. Alper K, Devisky O, Perrine K. Nonepileptic seizures and childhood sexual and physical abuse. Neurology 1993; 43: 1950-3.

22. Lesser RP. Psychogenic seizures. Neurology 1996; 46: 1499-507.

23. McGinley M, Carlo G. Two sides of the same coin? The relations between prosocial and physically aggressive behaviors. J Youth Adolescence 2007; 36: 337-49. 